ROCZNIKI TEOLOGICZNE

Tom LXVI, zeszyt 7 - 2019

DOI: https://dx.doi.org/10.18290/rt.2019.66.7-7

RAJMUND PORADA

\title{
DIALOGICAL CATHOLICITY OF THE CHURCH
}

\begin{abstract}
A b stract. The Church's catholicity is confessed by almost all Churches in the Christian Creed. However, as a result of historical divisions within Christianity, this attribute of the Church has often adopted confessional and narrow interpretations. The ecumenical activities are aimed at restoring the Catholic fullness and, therefore, the understanding of catholicity or the Catholic fullness of the Church must be closely related to the understanding of ecumenism. The article attempts to justify the thesis that catholicity of the Church, by its nature, has a dialogical dimension. It results from the constant tension between the multiplicity of ecclesial identities and the unity of the one people of God as an objective of ecumenism. The ecumenical way, however, does not omit the specificity of the confessional identity, but it demands recognition of the legitimate multiplicity and diversity of forms of expressing one Christian faith. According to the assumptions of the ecumenical hermeneutics, various ecclesial traditions should be interpreted in the light of what unites and not what divides, and the elements belonging to the ecumenically-, that is dialogically-oriented catholicity, should be noticed and recognised.
\end{abstract}

Key words: Church; catholicity; confessional identity; ecumenism.

In spite of the fact that the purpose of the Reformation was to renew the Church, one of its consequences was the emergence of many churches with diverse confessional identities. They can be called identities of relative nature, since they were shaped in mutual, not always friendly, relation to each other. Even a cursory analysis of the development of Catholic ecclesiology in the post-reform period shows that the competition of several confessions in a specific geographic territory led to the exclusive determination and normalization of what was owned. As a result of the process of confessionalising of Christianity, the medieval pluralism within one Church was replaced by the ideology of unity and integrity, which consisted in gradual elimination, from its own doctrine, the elements used for determining the identity of the competitive party, resulting in narrowing the current spectrum of church life. ${ }^{1}$ In

Rev. Dr hab. Rajmund PoRAdA, Prof. at UO - University of Opole (UO), Department of the Principles of Ecumenism; address for correspondence — e-mail: rajmund.porada@uni.opole.pl.

${ }^{1}$ Cf. D. MacCulloch, Die Reformation1490-1700 (München: Deutsche Verlags-Anstalt, 2008), 16. 
fact, this process can be called impoverishment, because the original "breadth" of the Christian identity has replaced the "multiplicity" of confession. The loss of this "breadth" caused the repression of pluralism, that is, what is confessionally possible, beyond its own limits. Its effect was, among others, the formation of confessionally understood catholicity. ${ }^{2}$ Since then, the concept of catholicity has met with some ambivalence. On the one hand, it has a confessional connotation that distinguishes one of the Churches (Catholic Church in the confessional sense) from others, and on the other hand, it is an attribute of the Church of Christ confessed by Christians in the Creed.

Rebuilding ecclesial unity means restoring the Catholic fullness that was lost as a result of the existing divisions. Since Vaticanum II's rejection of the way to restore unity through "return to Rome," understanding catholicity or the Catholic fullness of the Church must be closely related to the understanding of ecumenism. Dialogue remains its essential dimension, therefore catholicity itself should be understood in a dialogical perspective. Thus, the purpose of this article is to justify the thesis that the Church's catholicity, by nature, has a dialogical dimension. The goal set in this way determines the structure of this elaboration. First, we need to look at the very concept of catholicity in its etymological and historical development. Next, the process of "confessionalisation" of the notion of catholicity which led to narrowed approaches of Christian doctrine in divided churches has to be characterised. In the next steps, an ecumenical "discovery" and reflection on catholicity in this area and the implications for understanding catholicity as a reality having a dialogical dimension will be pointed out.

\section{CATHOLICITY IN ETYMOLOGICAL AND HISTORICAL PERSPECTIVE}

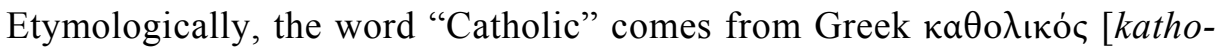

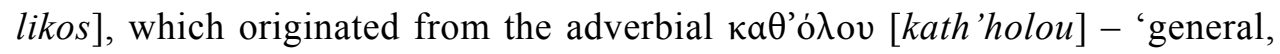

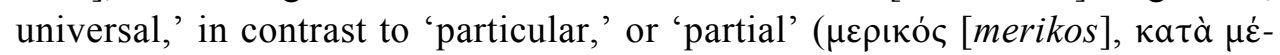

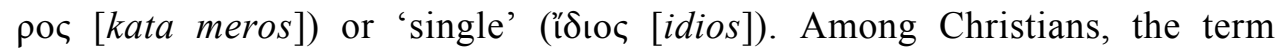
"Catholic" took on a whole series of special meanings. For instance, the word

\footnotetext{
${ }^{2}$ Cf. Peter NeunER, "Katholische Identität im religiösen Markt der Möglichkeiten," in Ökumene zwischen ,postmoderner Beliebigkeit“ and „Rekonfessionalisierung”, ed. Peter Neuner and Birgitta Kleinschwärzer-Meister (Münster, Hamburg, Berlin, London: LIT Verlag, 2006), 57ff; Karlheinz RuHSTORFER, Befreiung des „,Katholischen “. An der Schwelle zu globaler Identität (Freiburg, Basel, Wien: Herder, 2019), 35-37.
} 
could be used to describe the main church of the diocese, the archbishop or the superior of a group of monasteries. Most often, however, it was a predicate related to the Church, and for the first time in this sense it was used by Saint Ignatiusof Antioch, stating that "Wheresoever the bishop appears, there let the people be, even as wheresoever Christ Jesus is, there is the Catholic Church"

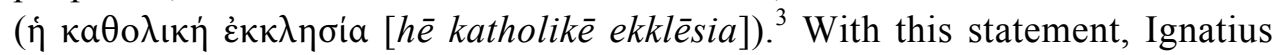
warns the Smyrneans against separatist assemblies and recalls that the bishop is the true centre of unity. With time, the "Catholic" predicate gained a dogmatic meaning that distinguished the Church from a sect. It is therefore assumed that from the middle of the $2^{\text {nd }}$ century both in the East and the West, the word "Catholic" is used to describe the true Church of Christ as opposed to heretical and schismatic groups.

One of the key biblical texts, which refers in substance to the reality expressed in this word, is the statement in the Letter to the Ephesians 1:22-23: "He has put all things under his feet, and made him, as he is above all things, the head of the Church; which is his Body, the fullness $(\pi \lambda \eta \dot{\rho} \omega \mu \alpha$ [plērōma]) of him who is filled, all in all". Saint Paul uses the Greek term $\pi \lambda \hat{\eta} \rho \omega \mu \alpha$ [plèrōma]. The question arises as to why the Church was not termed "pleromatic"? One of the reasons may be too strong link between this word and gnosis. To avoid false connotations, the term $\pi \lambda \eta \dot{\eta} \omega \mu \alpha$ [plērōma] was therefore abandoned. However, the term "Catholic" on one side was to express the Pauline idea of the fullness, and at the same time differentiated from the gnostic understanding of the term $\pi \lambda \eta \dot{\rho} \omega \mu \alpha\left[\right.$ plèroma.$^{4}$ However, the question arises, in what sense does the "Catholic" remain the equivalent of this ,fullness"?

In the aforementioned statement from the Letter to the Ephesians, "fullness" is another form of the expression: "His Body". Therefore, catholicity expresses the fact that the Church is the Body of Christ in its fullness and perfection. By referring to the text, Wolfgang Beinert states that catholicity expresses the fullness of Christian grace which based on the power of God's decision was entrusted to the Church in order to recreate the saving work of Christ until its eschatological fulfillment. ${ }^{5}$ Therefore, catholicity is associated with the person of Jesus Christ. In its deepest essence, it is an attribute or

\footnotetext{
${ }^{3}$ Letter to the Smyrnaeans, 8, in: http://www.earlychristianwritings.com/srawley/ smyrnaeans.html.

${ }^{4}$ Wolfgang BeIneRT, Um das dritte Kirchenattribut: Katholizität in der Geschichte der Theologie. Katholizität in der evangelisch-lutherischen Theologie, vol. I (Essen: Ludgerus Verlag Hubert Wingen KG. 1964), 407-409; Dominik SchultheIS, Die Katholizität der Kirche. Versuch einer Bestimmung der dritten notaecclesiae in der deutschsprachigen Systematischen Theologie seit dem Zweiten Vatikanum (Würzburg: Echter Verlag, 2015), 22.

${ }^{5}$ BeINERT, Um das dritte Kirchenattribut, 462.
} 
quality characterising Christ. Therefore, the Church is Catholic to such an extent in which it is rooted in Christ and based on Christ as its head. ${ }^{6}$

The evolution of the term "Catholic" in the first centuries resulted in the situation that a richer, more intense sense started to be assigned to it over time. One of the important texts referenced in this context is the $18^{\text {th }}$ catechesis of Cyril of Jerusalem of the 4th century. This doctor of the Church combines the geographical aspect of catholicity with its doctrinal and salvific aspects, associating the fullness of the means of salvation and truth with the word "Catholic."" This term, therefore, was used to distinguish the true, rightful Church from heretical assemblies. Therefore, the Church is called the Catholic Church because it is the place where Christ reigns and where he sacrifices himself in the complete fullness by the Holy Spirit. In other words, the Church is Catholic, if it is rooted in Christ and based on Christ's truth. In spite of exposure of various aspects of catholicity in the following centuries, this Christological connotation was decisive. It also proved to be particularly important in the face of the crisis caused by divisions within Christianity.

\section{2. “CONFESSIONALISATION"OF CATHOLICITY}

In the Middle Ages, the understanding of catholicity began to vary depending on the confessional conditions. The Eastern Churches directed their attention towards the qualitative aspect indicating that catholicity of the Church reflects the fullness of life of the Holy Trinity. ${ }^{8}$ In turn, in the West, catholicity was increasingly conceived in relation to the hierarchy. The position of Pope Innocent III, who understood catholicity as the fullness of power (plenitudo potestatis) of the Pope, is considered a peak of this development. ${ }^{9}$

The next step towards narrowing the concept of catholicity was made during the Reformation and Counter-Reformation periods. One of the important

\footnotetext{
${ }^{6}$ Dagmar Heller, "Catholicity under Pressure. The Ambiguous Relationship between Diversity and Unity: President's Address," ÖkumenischeRundschau - Beiheft Nr. 105 (2016): 22.

${ }^{7}$ Cyril of Jerusalem, Catechetical Lecture 18, in: The Catechetical Lectures of S. Cyril, Archbishop of Jerusalem, with a revised translation, introduction, notes, and indices, by Edwin Hamilton Gifford, http://www.documentacatholicaomnia.eu/03d/0313-0387,_Cyrillus_Hierosolymitanus, Catechetical_Lectures_[Schaff],_EN.pdf, p. 324.

${ }^{8}$ Cf. Theodor NiKOLAOU, "Katholizität, Orthodoxes Verständnis," in Hanfried KRÜGER Werner LÖSER and Walter MÜLlER-RÖMHELD, Ökumene-Lexikon. Kirchen - Religionen - Bewegungen (Frankfurt am Main: Lembeck Knecht 1987), 628; Heller, "Catholicity under Pressure," 23; SChultheis, Die Katholizität der Kirche, 35.

9Quoted from: Heller, "Catholicity under Pressure," 24.
} 
consequences of the Reformation movement was the emergence of many different churches in one territory. The occurred situation was novum compared to the effects of the $11^{\text {th }}$ century schism between the East and the West. Then there was "disintegration" of the entire territories which remained religiously homogeneous in their area. The post-reformation multiplicity of Churches contributed to the emergence of many competing types of ecclesiology. The rival and, at the same time, relativizing each other ecclesiologies affected the understanding of the Church. The competition of many Churches in the same geographical territory forced the recognition of the own identity in exclusive categories, and at the same time with its uniformisation, to the detriment of the earlier pluriformism of religious life within one Church. The old, medieval pluralism was replaced by identity and even the ideology of uniformity. ${ }^{10}$ The creation of competitive religious versions within Christianity could be observed on different sides of the reforming dispute. However, there is no doubt that during the Counter-Reformation period, the term "catholicity" was used in a polemical sense, as a distinctive feature in opposition to the reformers. In practice, it meant the exclusion of alternatives or at least varied ecclesiologies. The constrictions that had been taken strengthened a sense of otherness between various groups of Christians, especially, on the basis of competing doctrines that had developed as a result of their internal "purification" of diversity. ${ }^{11}$ Each confessional community essentially has a „centrifugal” structure, which, by generating centrifugal forces, drives away everything that poses even the appearance of a threat to its own identity. Thus, the original "breadth" of the Christian identity has replaced the „multiplicity” of confession. The loss of this "breadth" caused the repression of pluralism, that is, what is confessionally possible, beyond the limits of one's religion. Its effect was, among others, the formation of confessionally understood catholicity, which all new formed Churches and communities claimed the right to. ${ }^{12}$

\footnotetext{
${ }^{10}$ Johanna RAHNER, "Einheit und Vielfalt als Folge der Reformation und ekklesiologisches Problem," in Wem gehört die Reformation? Nationale und konfessionelle Dispositionen der Reformationsdeutung, ed. Günter Frank, Volker Leppin and Herman J. Selderhuis (Freiburg, Basel, Wien: Herder, 2013), 182.

${ }^{11}$ Cf. MacCulloch, Die Reformation, 16.

${ }^{12}$ Schultheis, Die Katholizität der Kirche, 40, 51-63; Rajmund Porada, "Urzeczywistnianie się Kościoła w dialogu ekumenicznym - perspektywa katolicka,” Studia Paradyskie 28 (2018): 75 .
} 


\section{MODERN ECCLESIAL SEARCH \\ FOR “RE-BROADENING”CATHOLICITY}

The Second Vatican Council, which reformed the theological thinking, proposed a way to free catholicity from confessional reductions caused by theological controversies of the Reformation and Counter-Reformation periods and the confessionalisation process of Christianity in that time. ${ }^{13}$ In the Dogmatic Constitution on the Church Lumen Gentium, the Council Fathers wrote that catholicity is the universality which "a gift from the Lord Himself. By reason of it, the Catholic Church strives constantly and with due effect to bring all humanity and all its possessions back to its source in Christ, with Him as its head and united in His Spirit" (No. 13). The Council confirmed the readiness of the Catholic Church to join and engage in the ecumenical movement. For this purpose, the principles for ecumenical commitment were defined. One of the main premises of the Catholic openness was awareness of the limitation, or even a defect of own catholicity in the face of a breakdown of Christianity into many Churches and communities. The awareness that the term "Catholic" is not synonymous with the term "Roman Catholic" was expressed in the Decree on Ecumenism Unitatis Redintegratio, stating that "the divisions among Christians prevent the Church from attaining the fullness of catholicity proper to her, in those of her sons who, though attached to her by Baptism, are yet separated from full communionwith her. Furthermore, the Church herself finds it more difficult to express in actual life her full catholicity in all her bearings" (No. 4). In the same decree, it was also stated that the process of internal renewal of the Church, which is somehow inscribed in its nature, should always aim at revealing, in its whole sense, at the same time, the universality and apostolicity of the Church (No. 4). In this sense, catholicity is not something static and permanent, but a certain obligation, a state that should be a constant objective of striving and whose measure is fidelity to the Gospel. ${ }^{14}$

In a similar vein, the meaning of "catholicity" was determined at the $5^{\text {th }}$ General Assembly of the World Council of Churches in 1968. In the report of Section I, which dealt with the topic: "The Holy Spirit and catholicity of the Church," it was written that catholicity is a gift of the Holy Spirit, as well as

\footnotetext{
${ }^{13}$ Wolfgang THÖNISSEN, Gerechtigkeit oder Barmherzigkeit. Das ökumenische Ringen um die Rechtfertigung (Paderborn, Leipzig: Bonifatius Verlag, Evangelische Verlagsanstalt, 2016), 197.

${ }^{14}$ Cf. Dorothea SATTLER, "Ökumenisch eine katholische Kirche werden? Das Verhältnis zwischen Vielfalt und Einheit aus (einer) römisch-katholischen Sicht," Ökumenische Rundschau - Beiheft Nr. 105 (2016): 75.
} 
a task, call and commitment. ${ }^{15}$ In the introduction to this report, it was stated that catholicity is not a sign or attribute of the Church, but rather a dynamic reality of the Church, which should constantly become Catholic. Catholicity is not a state, but a way of existence and life of the Church. It should not be equated with the external expansion of the Church and its widespread presence throughout the world, even if the geographical and quantitative aspect is an essential part of the Church's mission. However, the issue of catholicity concerns how to penetrate the world with spirit and fullness of life coming from communion with God. ${ }^{16}$ In this sense, catholicity should be expressed in the entire life of the Church and in all its elements.

In one of the latest documents of the World Council of Churches Commission on "Faith and Order" entitled The Church: Towards a Common Vision, catholicity is seen as a manifestation of God's goodness. The Church is Catholic, if it reveals this saving goodness of God and it is filled with it (No. 22). At the same time, the authors also found that: "The essential catholicity of the Church is undermined when cultural and other differences are allowed to develop into division" (No. 22). In the earlier document of the same commission entitled The Nature and Mission of the Church of 2005, it was found that the realisation of catholicity is possible in the communion of the Churches, in mutual recognition, and the Church is Catholic owing to the existence in the communion with other Churches. ${ }^{17}$

An analysis of the historical development of the understanding of catholicity and an ecumenical discourse over the meaning of this concept indicates that catholicity is closely related to the issue of unity, and at the same time, to the relationship between unity and diversity. ${ }^{18}$ Catholicity combines the diversity with the unity, the local aspect with the global aspect, and the contextual issues with the universal ones. It should be understood as the Church's task of finding the right balance between the diversity and the unity. ${ }^{19}$ The Church's catholicity confessed in Creed by all Christians must, therefore, be perceived as an imperative, which persuades to seek the unity in the diversity. Catholicity and ecumenism are closely related. It means that the ecumenical movement could be described as a movement that contributes to the growth of true

\footnotetext{
${ }^{15}$ Norman Goodall, The Uppsala Report 1968: Official report of the Fourth Assembly of the World Council of Churches, Uppsala July 4-20, 1968 (Geneva: World Council of Churches, 1968), 13.

${ }^{16}$ Ibid., 7.

${ }^{17}$ The Nature and Mission of the Church (Geneva: World Council of Churches, 2005), No. 55.

${ }^{18}$ Heller, "Catholicity under Pressure," 27.

${ }^{19}$ Ibid., 28-29.
} 
catholicity. ${ }^{20}$ Catholicity is the opposite of particularism, isolation, and sectarianism. It follows that if the isolation or re-emphasising of certain statements of faith leads to particularism, catholicity is disturbed by these reductions, and the fullness given in Christ is distorted. Therefore, in the era of ecumenism, the task of the Churches is to find a way to connect the multiplicity and differences with the unity again. In maintaining the balance between these poles, catholicity is realised. The dialogue understood as a friendly confrontation and a confrontation of diverse positions has a special role to play here. It should lead to a broader, full, and therefore, "Catholic" view of ecclesial reality. ${ }^{21}$ In other words, it should be a tool for seeking the ecumenical community integrating the multiplicity of confessional and religious differences. The ecumenical community assumes - apart from diverse confessional identities the existence of a Christian identity that refers to the fundamentals of the Christian faith. The tension between the multiplicity of confessional identities and the unity of the Christian identity, therefore, implies the way to ecumenical catholicity of one God's people in the multiplicity of church identities. ${ }^{22}$

\section{4. "ECUMENICAL"CATHOLICITY}

The above-mentioned way on the Catholic side was initiated by the Second Vatican Council. The Council Fathers proposed a fundamental change of perspective in looking at the own identity from "internal" to "external", i.e. that searching and finding the identity of the Church is performed through dialogue with the "outside" world. The "own" and "strange" do not represent something opposite and separated. ${ }^{23}$ It can be also referred to the intra-Christian dimension. In the eyes of the Council, the relationship of the Catholic Church towards other Churches and search for unity cannot depend on the

\footnotetext{
${ }^{20}$ Lukas VISCHER, "The Meaning of Catholicity — Preface," The Ecumenical Review 16 (1963): 24-25.

${ }^{21}$ RAHNER, "Einheit und Vielfalt," 183-184.

${ }^{22}$ Michael PlathOW, "Kirchliche Identitäten und ökumenische Katholizität," Ökumenische Rundschau - Beiheft Nr. 105 (2016): 390; Przemysław KANTYKA, "Dialog ekumeniczny katolicko-protestancki - założenia, zakres, rezultaty," in Ekumenizm w posoborowym pótwieczu. Sukcesy i trudności katolickiego zaangażowania na rzecz jedności chrześcijan, ed. Marcin Składanowski and Tadeusz Syczewski (Lublin: Wydawnictwo KUL, 2013), 32.

${ }^{23}$ Hans-Joachim SANDER, "Der Ort der Ökumene für die Katholizität der Kirche. Von der unmöglichen Utopie zur prekären Heterotopie," in Herders Theologischer Kommentar zum Zweiten Vatikanischen Konzil, vol. V: Theologische Zusammenschau und Perspektiven, ed. Peter Hünermann and Bernd Jochen Hilberath (Freiburg, Basel, Wien: Herder, 2006), 198.
} 
"collection" of lost "elements" and their incorporation into the Roman Catholic Church. For the ecclesial unity, it is indispensable and constitutive to stay in dialogue with other Churches and ecclesial communities and to recognise their faith and the practice of ecclesial life as an essential element of the Christian tradition. ${ }^{24}$ The Church realisation cannot be made in isolation from other religious traditions because it is also necessary to discover elements and endowments in them, "which together go to build up and give life to the Church itself [...]. All of these, which come from Christ and lead back to Christ, belong by right to the one Church of Christ" (DE 3). In the understanding of the Council, ecumenism means the ability to discover and recognise in others what belongs to the own tradition. On the one hand, it allows to shape the own profile, and on the other hand - it demands recognition of legitimate multiplicity and diversity of forms for expressing one Christian faith. The specific dialectics is possible owing to the ecumenical hermeneutics, according to which various ecclesiastical traditions should be interpreted in the light of what unites, and not what divides, observing some elements in it that belong to the ecumenically oriented catholicity. Although this paradigm shift in the analysis of the existing differences, involving the rejection of polemical theology, was initiated at a conference of the Commission "Faith and Order" in Lund (1952), it experienced significant strengthening at the Second Vatican Council. Conciliar aggiornamento represents a paradigm shift. It was possible by emphasising the biblical and theological foundations of faith and the Church, distinguishing between the content of faith and forms of its expression, the liturgy reform, using the "openness clause", that is a subsistit in formula in describing the way of the realisation of the Church of Christ in the world and moving away from depreciating terms "heretic" or "schismatist" in relation to non-Catholics. The ecumenism and methodological turn meant considering the common, kovvóv [koinon], as greater than what divides. ${ }^{25}$

In ecumenically practised ecclesiology, it should be assumed that being the Church is indispensably associated with the entry into coexistence with other Churches. In the ecclesial context, there is a commitment to the ecumenical

\footnotetext{
${ }^{24}$ Cf. RAHNER, "Einheit und Vielfalt," 197; Wojciech HANC, "Rzymskokatolickie rozumienie dialogu doktrynalnego," in Ekumenizm doktrynalny: schylek czy nowy poczatek?, ed. Tadeusz Kałużny and Zdzisław J. Kijas (Kraków: Wydawnictwo Naukowe UPJPII, 2018), 24; SANDER, "Der Ort der Ökumene für die Katholizität der Kirche," p. 194.

${ }^{25}$ Plathow, "Kirchliche Identitäten und ökumenische Katholizität," 385; Reinhard FRIELING, "Die ökumenische Bewegung vor einem Paradigmenwechsel?," in Ökumene zwischen „postmoderner Beliebigkeit" und "Rekonfessionalisierung", ed. Peter Neuner and Birgitta Kleinschwärzer-Meister (Münster, Hamburg, Berlin, London: LIT Verlag, 2006), 114-116.
} 
openness, not just an option for it. John Paul II, in the ecumenical encyclical Ut Unum Sint, openly stated that the ecumenical work is an imperative of the Christian conscience, ${ }^{26}$ and the ecumenical dialogue is a clear need, and even a necessity and one of the priorities of the Church. ${ }^{27}$ This does not automatically result in the necessity of recognising others as full realisation of the Church of Jesus Christ, and their theology and teaching as an expression of the Church unity ${ }^{28}$ Not so much pluralism as such, but legitimate multiplicity in the realisation of one Church of Jesus Christ demands recognition. Therefore, the search for unity is a dialogical confrontation of the own and foreign ecclesiological "topology." Charta Oecumenica adopted in 2001 by the Conference of European Churches and the Council of European Episcopal Conferences formulated this necessity in the form of a commitment, in order to "overcome the feeling of self-sufficiency within each church, and to eliminate prejudices [...]." ${ }^{29}$ Although the signatories of the Charta had in mind the broadly understood cooperation between the Churches, this obligation equally affects the doctrinal dimension and shaping of the confessional identity.

Catholicity does not mean uniformity of nor a Christian doctrine or ecclesiastical structures. It would be not only unrealistic, but even inconsistent with the way of the Church realisation in the initial period. The New Testament includes evidence that the first Christian communities, despite the diversity of forms of ecclesial services and organisations of church life, were aware of the establishment of one Church of Jesus Christ. The faith in triune God allowed to develop a dynamic understanding of the church unity. The concept of unity, which distances itself from monistic and monarchial ideas, and is based on the image of the community, was derived from the doctrine of the Holy Trinity. ${ }^{30}$ The consequence of such an approach should be the adoption of the principle of participation and dialogue and the rejection of authoritarianism. Therefore, the initiating of a dialogue by the Church does not constitute a neutral option,

\footnotetext{
${ }^{26}$ Cf. John Paul II, Encyclical Ut Unum Sint, No. 8.

${ }^{27}$ Ibid., No. 31.

${ }^{28}$ Cf. Friedrich Wilhelm Graf and Dieter KORSCH, "Jenseits der Einheit. Reichtum der Vielfalt. Der Widerstreit der ökumenischen Bewegungen und die Einheit der Kirche Jesu Christi, “ in Jenseits der Einheit. Protestantische Ansichten der Ökumene, ed. Friedrich Graf Wilhelm and Dieter Korsch (Hannover: Lutherisches Verlagshaus, 2001), 28; Stanisław Celestyn NAPIÓRKOWSKI, "Ekumenizm a personalizm," in Leonard GóRKA and Stanisław Celestyn NAPIÓRKOWSKI, Kościoły czy Kościót. Wybrane zagadnienia z ekumenizmu (Warszawa: Verbinum, 1995), $156 \mathrm{f}$.

${ }^{29}$ Charta Oecumenica, No. 3.

${ }^{30}$ Peter NeunER, "Dialog als Selbstverwirklichung der Kirche," Ökumenische Rundschau 59 (2010), 2: 193-194; RuHSTORfER, Befreiung des „Katholischen “, 39 ff.
} 
which would be only motivated by its importance in the contemporary culture, but it is the way of the Church realisation in its catholicity. ${ }^{31}$

The ecclesial identity is of a dynamic nature, and its deepening and strengthening should be necessarily performed through participation in the ecumenical work. In the light of the post-Conciliar Catholic ecclesiology, the ecumenical commitment can be seen as one of the structural elements of being the Church. It means the necessity of looking at own identity in the perspective of its dependency and relationship with others. This assignment should result in an inclusive form of conducting the ecumenical discourse in search for truth and realisation of catholicity of the Church.

By taking into account the current achievements of doctrinal dialogues, the conclusion is imposed that the ecumenical agreement is aimed at achieving the community based on the paradigm of reconciled diversity. In fact, it is related to the unity in diversity of the Churches, which mutually do not deny themselves being (though perhaps in a varied degree) the realisation of one Church of Jesus Christ. In this perspective, it can also be assumed that the objective of ecumenical activities is catholicity of the unity in a multitude of confessional identities, which grow on the foundation of Christian faith, that is, the confession of faith in triune God who revealed himself in Jesus Christ through the Holy Spirit for the salvation of man. ${ }^{32}$ In other words: the ecumenical catholicity derives from the tension between multiplicity and unity - between the multiplicity of ecclesial identities and the unity of the one people of God. The necessity of basing on the dialogical paradigm in continuous defusing of this tension results in the situation that catholicity of the Church should be called dialogical one.

\section{BIBLIOGRAPHY}

BEINERT, Wolfgang. Um das dritte Kirchenattribut: Katholizität in der Geschichte der Theologie. Katholizität in der evangelisch-lutherischen Theologie. Vol. I. Essen: Ludgerus Verlag Hubert Wingen KG, 1964.

FRIELING, Reinhard. "Die ökumenische Bewegung vor einem Paradigmenwechsel?” In Ökumene zwischen „postmoderner Beliebigkeit" und "Rekonfessionalisierung”, edited by Peter Neuner and Birgitta Kleinschwärzer-Meister, 103-130. Münster, Hamburg, Berlin, London: LIT Verlag, 2006.

\footnotetext{
${ }^{31}$ Cf. Porada, "Urzeczywistnianie się Kościoła w dialogu ekumenicznym," 80.

${ }^{32}$ Plathow, "Kirchliche Identitäten und ökumenische Katholizität," 22; cf. KANTYKA, "Dia$\log$ ekumeniczny katolicko-protestancki," 30; NEUNER, "Katholische Identität im religiösen Markt der Möglichkeiten," 68-69.
} 
Goodall, Norman. The Uppsala Report 1968. Official report of the Fourth Assembly of the World Council of Churches, Uppsala July 4-20, 1968. Geneva: World Council of Churches 1968

GRAF, Friedrich Wilhelm, and Dieter KORSCH. "Jenseits der Einheit. Reichtum der Vielfalt. Der Widerstreit der ökumenischen Bewegungen und die Einheit der Kirche Jesu Christi." In Jenseits der Einheit. Protestantische Ansichten der Ökumene, edited by Friedrich Graf Wilhelm and Dieter Korsch, 9-33 . Hannover: Lutherisches Verlagshaus, 2001.

HANC Wojciech. "Rzymskokatolickie rozumienie dialogu doktrynalnego.” In Ekumenizm doktrynalny: schyłek czy nowy poczqtek?, edited by Tadeusz Kałużny and Zdzisław Józef Kijas, 11-46. Kraków: Wydawnictwo Naukowe UPJPII, 2018.

Heller, Dagmar. "Catholicity under Pressure. The Ambiguous Relationship between Diversity and Unity: President's Address.” ÖkumenischeRundschau - Beiheft Nr. 105 (2016): 19-34.

KANTYKA, Przemysław. "Dialog ekumeniczny katolicko-protestancki — założenia, zakres, rezultaty." In Ekumenizm w posoborowym pótwieczu. Sukcesy i trudności katolickiego zaangażowania na rzecz jedności chrześcijan, edited by Marcin Składanowski and Tadeusz Syczewski, 29-50. Lublin: Wydawnictwo KUL, 2013.

MacCulloch, Diar Maid. Die Reformation 1490-1700. München: Deutsche Verlags-Anstalt, 2008.

NAPIÓRKOWSKI, Stanisław Celestyn. "Ekumenizm a personalizm.” In Kościoły czy Kościót. Wybrane zagadnienia z ekumenizmu, edited by Leonard Górka Stanisław Celestyn Napiórkowski, 151-185. Warszawa: Verbinum, 1995.

NeunER, Peter. "Dialog als Selbstverwirklichung der Kirche." Ökumenische Rundschau 59 (2010), 2: 190-205.

Neuner, Peter. "Katholische Identität im religiösen Markt der Möglichkeiten." In Ökumene zwischen ,postmoderner Beliebigkeit”and,, Rekonfessionalisierung”, edited by Peter Neuner and Birgitta Kleinschwärzer-Meister, 55-71. Münster, Hamburg, Berlin, London: LIT Verlag, 2006.

NiKOlAOU, Theodor. "Katholizität, Orthodoxes Verständnis." In Hanfried KRÜGER WernER LÖSER and Walter MÜLLER-RÖMHELD. Ökumene-Lexikon. Kirchen - Religionen - Bewegungen, 627-629. Frankfurt am Main: Lembeck Knecht 1987.

Plathow, Michael. "Kirchliche Identitäten und ökumenische Katholizität." Ökumenische Rundschau - Beiheft Nr. 105 (2016): 377-390.

PORADA, Rajmund. "Urzeczywistnianie się Kościoła w dialogu ekumenicznym - perspektywa katolicka." Studia Paradyskie 28 (2018): 69-82.

RAHNER, Johanna. Einheit und Vielfalt als Folge der Reformation und ekklesiologisches Problem. In Wem gehört die Reformation? Nationale und konfessionelle Dispositionen der Reformationsdeutung, edited by Günter Frank, Volker Leppin, and Herman J. Selderhuis, 182203. Freiburg, Basel, Wien: Herder, 2013.

RUHSTORfER, Karlheinz. Befreiung des „Katholischen“. An der Schwelle zu globaler Identität. Freiburg, Basel, Wien: Herder, 2019.

SANDER, Hans-Joachim. "Der Ort der Ökumene für die Katholizität der Kirche. Von der unmöglichen Utopie zur prekären Heterotopie.” in: Herders Theologischer Kommentar zum Zweiten Vatikanischen Konzil. Vol. V: Theologische Zusammenschau und Perspektiven, edited by Peter Hünermann and Bernd Jochen Hilberath, 188-200. Freiburg, Basel, Wien: Herder, 2006.

SATTLER, Dorothea. "Ökumenisch eine katholische Kirche werden? Das Verhältnis zwischen Vielfalt und Einheit aus (einer) römisch-katholischen Sicht." Ökumenische Rundschau Beiheft Nr. 105 (2016): 67-80. 
SCHUltheIS, Dominik. Die Katholizität der Kirche. Versuch einer Bestimmung der dritten nota ecclesiae in der deutschsprachigen Systematischen Theologie seit dem Zweiten Vatikanum. Würzburg: Echter Verlag, 2015.

THÖNISSEN, Wolfgang. Gerechtigkeit oder Barmherzigkeit. Das ökumenische Ringen um die Rechtfertigung. Paderborn, Leipzig: Bonifatius Verlag, Evangelische Verlagsanstalt, 2016.

VISCHER, Lukas. "The Meaning of Catholicity - Preface." The Ecumenical Review 16 (1963): 24-25.

\section{DIALOGICZNA KATOLICKOŚĆ KOŚCIOŁA}

\section{Streszczenie}

Katolickość Kościoła wyznają niemal wszystkie Kościoły w chrześcijańskim Credo. W wyniku jednak historycznych podziałów w obrębie chrześcijaństwa ten atrybut Kościoła przyjął nierzadko konfesyjne, zawężające interpretacje. Działania ekumeniczne zmierzają do przywrócenia katolickiej pełni, a zatem rozumienie katolickości czy też katolickiej pełni Kościoła musi pozostawać w ścisłym związku z rozumieniem ekumenizmu. W artykule podejmuje się próbę uzasadnienia tezy, że katolickość Kościoła ze swej natury ma wymiar dialogiczny. Wynika on ze stałego napięcia między wielością kościelnych tożsamości a jednością jednego ludu Bożego jako celu ekumenizmu. Ekumeniczna droga nie pomija jednak specyfiki konfesyjnej tożsamości, lecz domaga się uznania słusznej wielości i różnorodności form wyrażania jednej chrześcijańskiej wiary. Zgodnie z założeniami ekumenicznej hermeneutyki różne kościelne tradycje należy interpretować w świetle tego, co łączy, a nie tego, co dzieli, oraz dostrzegać i uznawać w nich elementy przynależące do ekumenicznie, czyli dialogicznie zorientowanej katolickości.

Słowa kluczowe: Kościół; katolickość; konfesyjna tożsamość; ekumenizm. 